\title{
Temperature effects on anatomy and digestibility of leaf and stem of tropical and temperate forage species
}

\author{
J. R. WILSON ${ }^{1 *}$, B. DEINUM ${ }^{1} \&$ F. M. ENGELS ${ }^{2 * *}$ \\ ${ }^{1}$ Department of Field Crops and Grassland Science, Wageningen Agricultural University, \\ Haarweg 333, NL 6709 RZ Wageningen, Netherlands ( ${ }^{*}$ Permanent address: CSIRO Divi- \\ sion of Tropical Crops and Pastures, 306 Carmody Road, St. Lucia, Brisbane, Australia \\ 4067. This work was done whilst the senior author was a visiting Professor at Wageningen \\ Agricultural University, Netherlands) \\ 2 Department of Plant Cytology and Morphology, Wageningen Agricultural University, Ar- \\ boretumlaan 4, NL 6703 BD Wageningen, Netherlands (** Present address: Department of \\ Field Crops and Grassland Science, Wageningen Agricultural University)
}

Received 5 October 1990; accepted 15 November 1990

\begin{abstract}
Growth temperature effects on anatomy and digestibility of leaf and stem of tropical and temperature forage species (Cynodon dactylon, Panicum maximum var. trichoglume, $P$. laxum, Lolium perenne and Medicago sativa), representing a range of anatomical types, was evaluated. Plants were grown in controlled-environment glasshouses at day/night temperatures of $32 / 26{ }^{\circ} \mathrm{C}$ or $22 / 16^{\circ} \mathrm{C}$. Tissues of defined development stage were sampled for analysis of proportion of cell types, cell wall thickness, staining properties and digestion, using transverse sections on microscope slides immersed in rumen fluid. Leaf and stem harvested from whole plant tops was analysed for organic matter digestibility (OMD), cell wall digestibility (DCW), lignin, cell wall and insoluble ash. Temperature had little consistent effect on the proportion of different cell types, or the thickness of cell walls, cell wall content or insoluble ash. The digestion of the walls of sclerenchyma, bundle sheath and xylem cells was lower in tissues grown at the higher temperature, especially for leaf. High temperature decreased OMD by an average of $6.6 \%$ units for leaf and $12.4 \%$ units for stem in the grasses, and by $2.6 \%$ units for both tissues in $M$. sativa. The decrease in OMD and DCW with high temperature (excluding stem of $\boldsymbol{M}$. sativa) was correlated with increase in lignin concentration ( $r=-0.96$ and 0.91 , respectively). High temperature appeared to increase intensity of lignification of the existing lignified cells rather than increase the proportion of cells becoming lignified. Staining intensity was an insensitive indicator of this change in lignification.
\end{abstract}

Keywords: plant anatomy, lignin, cell wall digestion, cell types, Panicum maximum, P. laxum, Cynodon dactylon, Lolium perenne, Medicago sativa

\section{Introduction}

High growth temperatures consistently reduce the digestibility of forage, whether it be tropical or temperature, grass or legume, or leaf or stem (Dirven \& Deinum, 
1977; Wilson, 1982). Change in total cell wall content with temperature is often small in relation to the change in dry or organic matter digestibility (e.g. Deinum, 1976; Wilson et al., 1976) or sometimes may differ in direction between species (Ford et al., 1979).

Also, the effect of temperature on lignin content, although usually positive, is not always closely related to the change in digestibility of cell wall (Deinum, 1984; Fales, 1986). However, the decrease in forage digestibility at high temperature is always associated with a substantial increase in the amount of indigestible cell wall (Deinum \& Dirven, 1976; Moir et al., 1977; Struik et al., 1985; Fales, 1986). Whether this increase in indigestible cell wall is associated with temperature effects on anatomical structure of leaf and stem altering the proportion of particular cell types within these tissues or on the degree of digestibility of particular cell walls is still largely unknown (Deinum, 1984).

Akin et al. (1987) looked at the leaf anatomy of tall fescue grown at different temperatures and concluded that, whilst there was a small increase in vascular tissue with higher temperature, the proportion of different tissues in cross-sectional area was in general little affected by growth temperature. Da Silva et al. (1987), in a study of three grasses, came to similar conclusion that tissue proportions in the leaf were not affected by temperature, but in the stem they found an increase in bundle sheath area with higher temperature in one species. One study had looked at the lignin staining reactions of specific cell walls. Akin et al. (1987) found that whilst the intensity of acid-phloroglucinol staining of leaf sclerenchyma was increased by high temperature, the reaction of other tissues to acid-phloroglucinol and chlorine sulphite was generally unaffected by growth temperature. The information on whether growth temperature alters digestibility through effects on proportions of different cell types, changes in thickness of their cell walls or degree of lignification or other changes affecting the digestion of specific cell walls remains very limited. This lessens our capacity to consider ways in which the effect of high growth temperature on digestibility may be minimized.

This study examines the effect of growth temperature on leaf and stem anatomy, and digestibility of specific cell types, for four grasses and one legume chosen to provide different types of anatomical structure.

\section{Material and methods}

\section{Plant material and growing conditions}

Five pasture species were used to evaluate the influence of growth temperature on the anatomical and digestion characteristics of leaf and stem tissue. The species were chosen to represent a variety of anatomical types, viz. a legume and a range of grass types with different photosynthetic pathways and associated differences in leaf anatomy (Hattersley, 1987; Wilson \& Hattersley, 1989). The species were:

- Cynodon dactylon cv. Burton; C4 NAD-ME type tropical grass,

- Panicum maximum var. trichoglume cv. Petrie; C4 PCK type tropical grass,

- Panicum laxum; C3 tropical grass, 
- Lolium perenne cv. Wendy; C3 temperate grass,

- Medicago sativa cv. Resis; C3 type temperate/subtropical legume.

The experimental plants were raised from seed sown on 6 July 1986 into a peat:sand:vermiculite mix in $30 \mathrm{~cm}$ diameter, black plastic pots, except for $M$. sati$v a$ and $C$. dactylon which were established vegetatively at the same time using local material from the field at Wageningen and cuttings from Australia, respectively. There were 12 pots for each species, each containing four plants. The plants were grown in environmentally controlled glasshouses at Wageningen Agricultural University, initially under standard conditions of $25 / 20^{\circ} \mathrm{C}$ day/night temperature. On 16 September, one half the number of pots were transferred to a glasshouse at $32 / 26{ }^{\circ} \mathrm{C}$ and the other half to a glasshouse at $22 / 16^{\circ} \mathrm{C}$; these temperatures were maintained to the end of the experiment. Relative humidity was about $60 \%$ during the day and above $85 \%$ at night. The plants received natural daylight supplemented with artificial light from a bank of six $400 \mathrm{~W}$ mercury iodide lamps to give a 12 hour photoperiod. The pots were arranged in three replicate blocks, with two pots of each species per block, and were randomized within blocks each week. The plants were kept well-watered and fertilized with a full nutrient mix.

The plants were trimmed to $10 \mathrm{~cm}$ height on 16 September and 8 October, and then left to grow until specific leaf and stem material was sampled on 25 November for measurement of anatomy, staining characteristics and digestion. Rate of leaf appearance expressed as days to expand a new leaf was measured for both temperature treatments in the pre-harvest period between 21 October and 6 November for 15 vegetative tillers or stems per species. At the completion of the experiment on 27 November, one plant of each species from each pot was cut at $5 \mathrm{~cm}$ height and the top material separated into green leaf (blade for grasses and blade plus petiole for $M$. sativa) and stem (including leaf sheath for grasses). These bulk samples were dried at $80^{\circ} \mathrm{C}$ overnight, ground to pass a $1 \mathrm{~mm}$ screen, and kept for measurement of organic matter and cell wall digestibility and for chemical analysis.

\section{Tissue anatomy, staining characteristics and digestion of cell types}

Sampling procedure. On 11 November, the penultimate fully expanded leaf on several vegetative stems per species per replicate was identified in each treatment by a coloured tag. On this day and fourteen days later on 25 November one of these tagged leaves from each replicate was harvested and placed in water to maintain turgidity. These leaves are regarded as young adult and fully mature leaves respectively, and depending on the rate of new leaf appearance (Table 1), the fully mature leaves on 25 November ranged from the third fully expanded leaf from the top of the stem (e.g. P. laxum) to the sixth (e.g. C. dactylon at high temperature). A 20 $\mathrm{mm}$ portion was taken from the midpoint of each leaf and from it a series of $100 \mu \mathrm{m}$ thick transverse sections were cut using a rotary arm microtome. Several of these sections were fixed in formalin-acetic acid-alcohol (FAA) mixture and stored for measurement of tissue anatomy. The remainder were pressed lightly onto doublesided sticky tape attached to the lower half of microscope slides. Two leaf sections were provided for each treatment/replicate and six sets of slides were prepared and 
Table 1. Comparison of the leaf appearance rate (days to expand a new leaf) on vegetative tillers or stems grown at high $\left(32 / 26^{\circ} \mathrm{C}\right)$ or low $\left(22 / 16^{\circ} \mathrm{C}\right)$ day/night temperatures.

\begin{tabular}{lrrl}
\hline Species & \multicolumn{2}{l}{ Growth temperature } & \multicolumn{1}{l}{$\begin{array}{l}\text { Significance } \\
\text { of difference }\end{array}$} \\
\cline { 2 - 2 } \multicolumn{1}{l}{$32^{\circ} \mathrm{C}$} & $22{ }^{\circ} \mathrm{C}$ & \\
C. dactylon & $2.8 \pm 0.2$ & $6.6 \pm 0.2$ & $* * *$ \\
$P$. maximum & $4.6 \pm 0.3$ & $9.2 \pm 0.5$ & $* * *$ \\
$P$. laxum & $9.4 \pm 0.5$ & $14.2 \pm 2.0$ & $*$ \\
L. perenne & $10.2 \pm 0.5$ & $8.7 \pm 0.4$ & $* *$ \\
M. sativa & $5.6 \pm 0.5$ & $4.2 \pm 0.2$ & $\mathrm{~ns}$ \\
\hline
\end{tabular}

${ }^{1} t$-test; ${ }^{* *} P<0.001 ;{ }^{* *} P<0.01 ;{ }^{*} P<0.05 ;$ ns $=$ not significant.

stored in water at $4{ }^{\circ} \mathrm{C}$. Sections from all species and both temperature treatments were represented on each slide. Results were somewhat more explicit on 25 November than on 11 November, hence only the former are summarized here for simplicity.

Samples of stem were collected on the 25 November as follows: for $P$. maximum and $P$. laxum the sample was the second internode from the top of flowering stems at anthesis; for $C$. dactylon it was the internode subtending the 'tagged' leaf (viz. the fourth or sixth elongated internode from the tip of the still vegetative stems for the low and high temperature treatments, respectively) and for $M$. sativa it was the fifth fully elongated internode from the top (about midheight of the stem). L. perenne was unvernalized and did not produce any elongated culms. A $20 \mathrm{~mm}$ portion was taken from the midpoint of one internode from each replicate and from it a series of $100 \mu \mathrm{m}$ sections were cut and placed into fixative or onto the same microscope slides as for the leaves.

Anatomy. The FAA-fixed portions, one from each replicate, was plastic-embedded, sectioned at $5 \mu \mathrm{m}$ and stained with aniline blue and toluidine blue. The proportions of different cell types, expressed as a percentage of total transverse sectional area, were determined using an electronic digitizer for a section of the lamina between the perpendicular bisectors of two major bundles at a point midway between the midrib and leaf margin, and separately for the midrib. Tissue proportions, vascular bundle number and size, and width of the sclerenchyma ring were measured on a quarter segment of each stem. Where the pith contained a central hollow, this area was excluded and tissue areas were expressed as a percentage of total area occupied by cells.

Thickness of the cell wall of sclerenchyma and metaxylem vessels in leaf and stem was measured using a verner-scaled ocular micrometer for 20 cells per replicate, except for the metaxylem cells in the leaf where only 10 cells were measured. Metaxylem vessels were measured in major vascular bundles in the grasses, and in the $M$. sativa stem near the midpoint of the xylem ring. Sclerenchyma cells measured were those associated with the major vascular bundles in the leaf and those at a point in the sclerenchyma ring midway between adjacent vascular bundles in the stem. 
Staining characteristics. One set of fresh sections on a microscope slide for each replicate was stained in acid phloroglucinol, and another set in chlorine sulphite (Akin et al., 1987), to assess the intensity of lignin/phenolic staining of the xylem and sclerenchyma cells associated with major vascular bundles in the leaf and stem tissues. The degree of staining was rated under a binocular microscope at $\times 40$ magnification on a scale of 0 (no visible stain colour) to 4 (deep red/purple), and the mean rating for the three replicates determined. Measurements were made within five minutes of the colour developing.

Tissue digestion procedure. Three sets of fresh sections on microscope slides were taken for each replicate and allocated for digestion in rumen fluid for either 10, 24 or $48 \mathrm{~h}$. The procedure used was an adaptation of the section to slide technique of Akin (1982) with slides suspended in a 1:2 rumen fluid:buffer mixture (McDougall, 1948), pH 6.95, kept at $39^{\circ} \mathrm{C}$ in a 21 beaker sealed with parafilm and bubbled continuously with $\mathrm{CO}_{2}$. Ground maize meal $\left(5 \mathrm{~g} \mathrm{l}^{-1}\right)$ and tripticase $\left(2 \mathrm{~g} \mathrm{l}^{-1}\right)$ were added as energy and protein sources. A fourth set of sections was similarly incubated for 48 hours in boiled rumen fluid/buffer mixture as a control. After digestion, slides were gently rinsed and the sections covered with a cover slip and examined under a microscope to estimate the percentage disappearance of each cell type in leaf and stem. Digestive thinning of the walls of the strongly lignified metaxylem and sclerenchyma cells in the stem was assessed by matching identical cells in control and 48-hour-digested sections and measuring change in wall thickness using an ocular micrometer at $\times 400$. Ten cells for metaxylem and 12 for sclerenchyma were measured for each replicate, and these cells were chosen at various positions within the stem section.

\section{Digestion and chemical analysis of bulk tissues}

The dried, ground samples of leaf and stem from the harvested plant tops were analysed for nitrogen, ash, cell wall content and digestibility of organic matter (OMD) and of cell wall (DCW (Deinum et al., 1981). Neutral detergent fibre, acid detergent lignin and insoluble ash were estimated by the methods of Goering \& van Soest (1970), with neutral detergent fibre corrected for protein contamination (Wilson \& $\mathrm{Ng}, 1975)$ to give an estimate of cell wall content (CWC).

\section{Statistical analyses}

Most data were subjected to analysis of variance, with angular transformations made for the estimates of percentage digestion. Comparisons of rate of leaf development and cell wall thickness were made using the standard Student's $t$-test. 


\section{Results}

Plant growth and leaf development

All species grew well at both temperatures and dry matter yields per plant (data not shown) after 50 days of regrowth were $5-8 \mathrm{~g}$ for $L$. perenne and 10-19 $\mathrm{g}$ for the other species, with grasses having 50 to $>100$ tillers per plant. The plants had been cut several times and were thus well past the initial seedling growth stage at the time of sampling.

Rate of new leaf appearance for the three tropical grasses ( $C$. dactylon, $P$. maximum and $P$. laxum) at $32{ }^{\circ} \mathrm{C}$ was substantially faster than at $22{ }^{\circ} \mathrm{C}$ (Table 1 ). The opposite occurred for the temperate $L$. perenne, and $M$. sativa had similar rates of leaf development at both temperatures.

\section{Digestibility and composition of bulk leaf and stem tissues}

Differences in \% insoluble ash between temperature treatments were small and inconsistent (Table 2). The effect of temperature on CWC was also variable, general-

Table 2. Effect of growth temperature on the lignin, insoluble ash and cell wall content (CWC), in vitro organic matter digestibility (OMD) and true cell wall digestibility (DCW) of leaf and stem tissue.

Species and plant part

\section{Leaf blade}

C. dactylon

$P$. maximum

$P$. laxum

L. perenne

$M$. sativa

Species $\times$ temperature interaction

LSD $(P<0.05)$

\begin{tabular}{|c|c|c|c|c|}
\hline Ast & $(\%)$ & n (\%) & OMD (\%) & DCW (\%) \\
\hline 4 & $\mathrm{C}$ & ${ }^{\circ} \mathrm{C}$ & C & $32{ }^{\circ} \mathrm{C}$ \\
\hline
\end{tabular}

\section{Stem}

C. dactylon

$P$. maximum

P. laxum

L. perenne ${ }^{J}$

$M$. sativa

$\begin{array}{ll}1.2 & 1.7 \\ 0.8 & 0.8 \\ 2.9 & 1.6 \\ 1.8 & 0.8 \\ 0.6 & 1.2\end{array}$

$\begin{array}{llll}51.4 & 37.3 & 2.2 & 1.3 \\ 39.4 & 44.0 & 2.6 & 1.8 \\ 44.6 & 38.5 & 2.3 & 1.6 \\ 33.0 & 29.2 & 1.8 & 1.4 \\ 10.6 & 10.1 & 1.4 & 0.8\end{array}$

$\begin{array}{ll}69.4 & 80.2 \\ 75.8 & 78.1 \\ 73.0 & 80.4 \\ 77.4 & 83.4 \\ 81.0 & 83.5\end{array}$

$62.0 \quad 75.2$

$66.6 \quad 74.2$

65.076 .1

$65.7 \quad 78.3$

$22.2 \quad 42.0$

Species $\times$ temperature interaction LSD $(P<0.05)$

$\begin{array}{ll}0.6 & 1.1 \\ 0.8 & 0.8 \\ 1.4 & 2.2 \\ \text { nd } & \text { nd } \\ 0.7 & 0.5\end{array}$

$\begin{array}{llll}64.1 & 57.4 & 6.7 & 3.4 \\ 64.8 & 63.8 & 6.8 & 4.2 \\ 55.0 & 51.1 & 5.0 & 3.0 \\ 50.5 & 37.5 & \text { nd } & \text { nd } \\ 41.9 & 42.0 & 9.9 & 8.6\end{array}$

50.0
49.7
54.8
72.8
57.8

64.8 66.2 64.8 81.1

$40.8 \quad 59.8$

$42.1 \quad 64.7$

$\begin{array}{ll}41.6 & 54.8\end{array}$

$68.6 \quad 78.2$

0.7

60.4

$29.9 \quad 36.0$

\footnotetext{
${ }^{1}$ Leaf sheath only (no true stem).

nd $=$ not determined.

$\mathrm{ns}=$ not significant $;{ }^{*} P<0.05,{ }^{* *} P<0.01,{ }^{* * *} P<0.001$.
} 
ly values were higher at $32{ }^{\circ} \mathrm{C}$ than at $22{ }^{\circ} \mathrm{C}$ but in a number of comparisons the differences were not significant, and for $P$. maximum leaf the $\mathrm{CWC}$ at $32{ }^{\circ} \mathrm{C}$ was lower $(P<0.05)$ than at $22^{\circ} \mathrm{C}$. However, \% lignin was consistently increased by high growth temperature, with the effect being greater for the stem than the leaf. OMD of leaf and stem was consistently lower at $32{ }^{\circ} \mathrm{C}$ than at $22^{\circ} \mathrm{C}$, with the difference being larger for the grasses than for $M$. sativa and for the stem than the leaf; average difference for grasses was $6.6 \%$ units for leaf and $12.4 \%$ units for stem, and for $M$. sativa it was $2.6 \%$ units for leaf and stem. Digestibility of cell wall was most strongly affected by temperature, with $\mathrm{DCW}$ lower at $32{ }^{\circ} \mathrm{C}$ than at $22^{\circ} \mathrm{C}$ in all treatments.

Lignin content expressed as a percentage of $\mathrm{CWC}$ was higher at $32{ }^{\circ} \mathrm{C}$ than at $22^{\circ} \mathrm{C}$ for both leaf and stem tissue (Figure 1), and DCW for the grasses was linearly $(P<0.001)$ and negatively correlated with this parameter $(r=-0.91)$. DCW of $M$. sativa leaf fell on the same relationship, but DCW of the stem did not, the values at both temperatures being much higher than expected from the lignin/cell wall content percentage (Figure 1). Figure 1 shows the overall linear regression for the grasses, individual regressions for the high and low temperature data showed no significant difference in either intercept or slope. The relationship (not presented) between OMD and lignin content of dry matter (OMD \% = 87.3-5.8 lignin \%) was equally good $(r=-0.96, P<0.001)$ to that shown in Figure 1 , with the $M$. sativa stem values again appearing as outliers.

\section{Digestible cell wall (\%)}

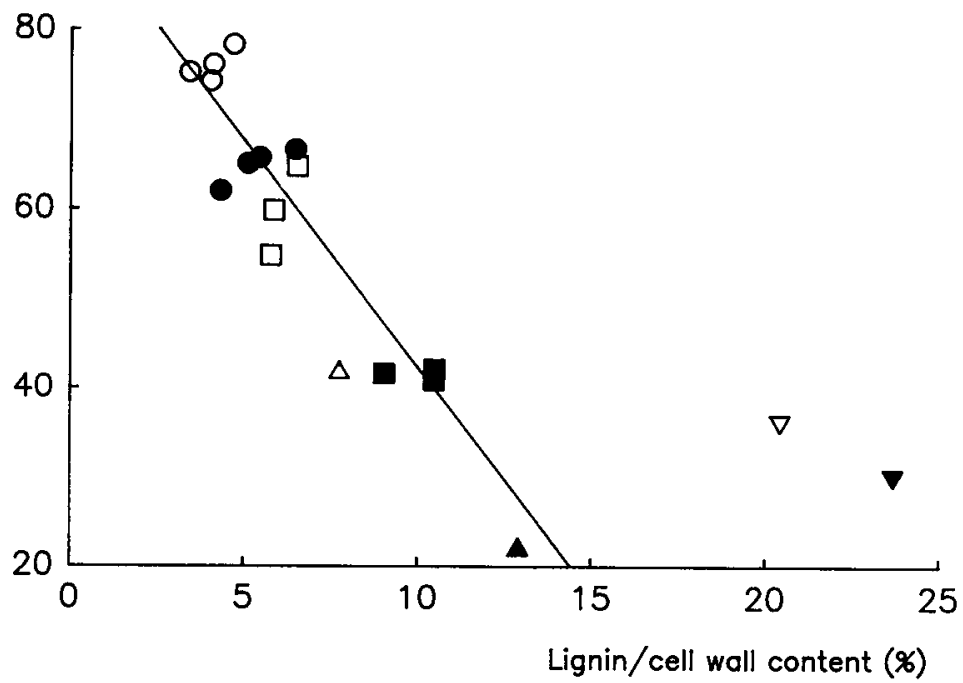

Fig. 1. Relationship between cell wall digestibility (\%) and lignin as a proportion of cell wall content $(\%)$ for grass leaf $(O, \Theta)$ and stem $(\square, \boldsymbol{\square})$ and legume leaf $(\Delta, \Delta)$ and stem $(\nabla, \nabla)$ grown at $22 / 16^{\circ} \mathrm{C}$ (open symbols) and $32 / 26^{\circ} \mathrm{C}$ (closed symbols). Regression line $\left(Y=92.9-5.05 X, r=-0.91^{* * *}\right)$ is for the grasses only. 


\section{Tissue anatomy and staining characteristics}

Tissue proportions. The proportion of different cell types in the blade and midrib of the leaf was little affected by temperature (Table 3 ). Significant species variation in temperature response $(P<0.05)$ was seen only in the epidermis and vascular tissue of the blade and the parenchyma bundle sheath of the midrib. These interactions were not consistently expressed in the same cell type in both blade and midrib and thus are unlikely to reflect real alteration of leaf structure in response to tempera-

Table 3. Effect of growth temperature on the anatomy of leaf blade and midrib expressed as the $\%$ of different cell types in cross-sectional area.

\begin{tabular}{|c|c|c|c|c|c|c|c|c|c|c|c|c|}
\hline \multirow{2}{*}{$\begin{array}{l}\text { Species and } \\
\text { plant part }\end{array}$} & \multicolumn{2}{|l|}{ MES $^{1}$} & \multicolumn{2}{|l|}{ EPI } & \multicolumn{2}{|l|}{ PBS } & \multicolumn{2}{|l|}{ PHL } & \multicolumn{2}{|l|}{ VAS } & \multicolumn{2}{|l|}{ SCL } \\
\hline & $32^{\circ} \mathrm{C}$ & $22^{\circ} \mathrm{C}$ & $32{ }^{\circ} \mathrm{C}$ & $22^{\circ} \mathrm{C}$ & $32{ }^{\circ} \mathrm{C}$ & $22^{\circ} \mathrm{C}$ & $32{ }^{\circ} \mathrm{C}$ & $22^{\circ} \mathrm{C}$ & $32^{\circ} \mathrm{C}$ & $22^{\circ} \mathrm{C}$ & $32{ }^{\circ} \mathrm{C}$ & $22^{\circ} \mathrm{C}$ \\
\hline \multicolumn{13}{|l|}{ Leaf blade } \\
\hline $\begin{array}{l}\text { C. dactylon } \\
\text { P. maximum } \\
\text { P. laxum } \\
\text { L. perenne } \\
\text { M. sativa }\end{array}$ & $\begin{array}{l}38.3 \\
40.9 \\
51.6 \\
58.7 \\
82.0\end{array}$ & $\begin{array}{l}37.3 \\
42.4 \\
51.9 \\
57.9 \\
78.3\end{array}$ & $\begin{array}{l}24.4 \\
30.7 \\
29.9 \\
29.4 \\
13.2\end{array}$ & $\begin{array}{l}23.5 \\
25.8 \\
29.9 \\
33.2 \\
17.9\end{array}$ & $\begin{array}{c}28.2 \\
21.9 \\
13.8 \\
6.2 \\
\text { na }\end{array}$ & $\begin{array}{r}30.2 \\
24.8 \\
13.8 \\
5.5 \\
\text { na }\end{array}$ & $\begin{array}{l}0.7 \\
0.4 \\
0.3 \\
0.6 \\
1.0\end{array}$ & $\begin{array}{l}0.5 \\
0.5 \\
0.3 \\
0.4 \\
1.0\end{array}$ & $\begin{array}{l}6.3 \\
4.9 \\
3.3 \\
4.0 \\
2.9\end{array}$ & $\begin{array}{l}6.0 \\
5.7 \\
3.3 \\
2.7 \\
2.2\end{array}$ & $\begin{array}{l}2.0 \\
1.0 \\
1.0 \\
1.0 \\
0.9\end{array}$ & $\begin{array}{l}2.4 \\
0.8 \\
0.9 \\
0.5 \\
0.6\end{array}$ \\
\hline Mean & 54.3 & 53.5 & 25.5 & 26.1 & 17.6 & 18.6 & 0.6 & 0.5 & 4.3 & 4.0 & 1.2 & 1.0 \\
\hline $\begin{array}{l}\text { Species } \times \\
\quad \text { temperature } \\
\text { interaction } \\
\text { LSD } \\
\quad(P<0.05)\end{array}$ & \multicolumn{2}{|l|}{ ns } & \multicolumn{2}{|l|}{$*$} & ns & & 0. & & 0.9 & & ns & \\
\hline \multicolumn{13}{|l|}{ Midrib $^{2}$} \\
\hline $\begin{array}{l}\text { C. dactylon } \\
P . \text { maximum } \\
P . \text { laxum } \\
\text { L. perenne } \\
\text { M. sativa }\end{array}$ & $\begin{array}{l}29.5 \\
62.7 \\
44.4 \\
52.9 \\
71.8\end{array}$ & $\begin{array}{l}32.2 \\
64.4 \\
45.1 \\
60.4 \\
72.9\end{array}$ & $\begin{array}{l}21.8 \\
11.1 \\
24.4 \\
27.4 \\
11.8\end{array}$ & $\begin{array}{l}20.9 \\
10.5 \\
22.7 \\
28.8 \\
13.0\end{array}$ & $\begin{array}{c}24.0 \\
14.0 \\
20.1 \\
8.6 \\
\mathrm{na}\end{array}$ & $\begin{array}{c}27.8 \\
13.1 \\
21.2 \\
4.9 \\
\text { na }\end{array}$ & $\begin{array}{l}3.8 \\
1.1 \\
1.0 \\
1.3 \\
4.8\end{array}$ & $\begin{array}{l}3.3 \\
1.3 \\
0.7 \\
0.8 \\
4.1\end{array}$ & $\begin{array}{r}14.5 \\
7.1 \\
7.0 \\
7.5 \\
6.1\end{array}$ & $\begin{array}{r}11.7 \\
6.7 \\
7.1 \\
3.8 \\
5.3\end{array}$ & $\begin{array}{l}6.3 \\
4.0 \\
3.1 \\
2.4 \\
5.5\end{array}$ & $\begin{array}{l}4.0 \\
4.0 \\
3.1 \\
1.2 \\
4.7\end{array}$ \\
\hline Mean & $52.3^{*}$ & 55.0 & 19.3 & 19.2 & 16.7 & 16.8 & 2.4 & 2.0 & $8.5^{* *}$ & 6.9 & 4.2 & 3.5 \\
\hline $\begin{array}{l}\text { Species } \times \\
\text { temperature } \\
\text { interaction } \\
\text { LSD } \\
\quad(P<0.05)\end{array}$ & \multicolumn{2}{|l|}{ ns } & \multicolumn{2}{|l|}{ ns } & \multicolumn{2}{|l|}{ * } & \multicolumn{2}{|c|}{ ns } & \multicolumn{2}{|l|}{ ns } & \multicolumn{2}{|l|}{ ns } \\
\hline
\end{tabular}

${ }^{1}$ MES = mesophyll, including parenchyma in midrib where present; $\mathrm{EPI}=$ epidermis; $\mathrm{PBS}=$ parenchyma bundle sheath; $\mathrm{PHL}=$ phloem; VAS = vascular tissue ex phloem; $\mathrm{SCL}=$ sclerenchyma in grasses and collenchyma in midrib of $M$. sativa.

${ }^{2}$ Midrib as proportion of total leaf cross-section area for $32{ }^{\circ} \mathrm{C}$ and $22{ }^{\circ} \mathrm{C}$ treatment respective: $C$. dactylon 6.9 and $7.1 ; P$. maximum 12.6 and $19.0 ;$ P. laxum 6.4 and $4.1 ;$ L. perenne 9.4 and 14.1 . LSD $P<0.05$ $=2.4$ ( $M$. sativa was not measured).

na $=$ not applicable

ns $=$ non-significant; ${ }^{*} P<0.05 ;{ }^{*} P<0.01$. 
ture.

The stem also showed no significant difference in proportions of individual cell types between temperatures, except for a decrease in total lignified tissue at $32{ }^{\circ} \mathrm{C}$ compared to $22^{\circ} \mathrm{C}$ (Table 4). Average stem diameter, vascular bundle size and width of the sclerenchyma ring were also significantly lower at $32{ }^{\circ} \mathrm{C}$ than at $22{ }^{\circ} \mathrm{C}$. Number of vascular bundles per stem did not differ between temperature treatments. The species $\times$ temperature interaction was non-significant for all stem attributes.

Table 4. Effect of growth temperature on (a) the anatomy (tissue proportions as a \% of cross-sectional area) and (b) morphology of stem.

(a) Tissue proportions

\begin{tabular}{|c|c|c|c|c|c|c|c|c|c|c|c|c|c|c|}
\hline \multirow[t]{3}{*}{ Species } & \multicolumn{2}{|c|}{$\mathrm{CHL}^{1}$} & \multicolumn{2}{|c|}{ EPI } & \multicolumn{2}{|c|}{ PAR } & \multicolumn{2}{|c|}{ PHL } & \multicolumn{2}{|c|}{ VAS } & \multicolumn{2}{|l|}{ SCL } & \multicolumn{2}{|c|}{ Total lig. ${ }^{2}$} \\
\hline & 32 & 22 & 32 & 22 & 32 & 22 & 32 & 22 & 32 & 22 & 32 & 22 & 32 & 22 \\
\hline & ${ }^{\circ} \mathrm{C}$ & ${ }^{\circ} \mathrm{C}$ & ${ }^{\circ} \mathrm{C}$ & ${ }^{\circ} \mathrm{C}$ & ${ }^{\circ} \mathrm{C}$ & ${ }^{\circ} \mathrm{C}$ & ${ }^{\circ} \mathrm{C}$ & ${ }^{\circ} \mathrm{C}$ & ${ }^{\circ} \mathrm{C}$ & ${ }^{\circ} \mathrm{C}$ & ${ }^{\circ} \mathrm{C}$ & ${ }^{\circ} \mathrm{C}$ & ${ }^{\circ} \mathrm{C}$ & ${ }^{\circ} \mathrm{C}$ \\
\hline C. dactylon & 26.9 & 23.5 & 2.5 & 2.8 & 49.2 & 48.5 & 3.4 & 3.2 & 10.4 & 12.8 & 7.6 & 9.3 & 18.0 & 22.1 \\
\hline P. maximum & 4.3 & 6.1 & 2.6 & 2.6 & 72.1 & 67.3 & 1.4 & 1.8 & 8.9 & 10.7 & 10.6 & 11.5 & 19.5 & 22.2 \\
\hline P. laxum & 12.5 & 11.8 & 3.0 & 3.1 & 68.0 & 66.5 & 1.1 & 1.2 & 8.6 & 9.2 & 6.9 & 8.2 & 15.5 & 17.4 \\
\hline$M$. sativa & 9.6 & 6.3 & 3.6 & 2.9 & 39.8 & 29.7 & 12.1 & 13.0 & 21.8 & 31.8 & 3.0 & 3.7 & 24.8 & 35.5 \\
\hline Mean & 13.3 & 11.9 & 2.9 & 2.8 & 57.3 & 53.0 & 4.5 & 4.8 & 12.4 & 16.1 & 7.0 & 8.2 & $19.5^{*}$ & 24.3 \\
\hline \multicolumn{15}{|l|}{$\begin{array}{l}\text { Species } \times \\
\text { temperature } \\
\text { interaction }\end{array}$} \\
\hline interaction & \multirow{2}{*}{\multicolumn{2}{|c|}{$\begin{array}{l}\text { ns } \\
4.9\end{array}$}} & \multirow{2}{*}{\multicolumn{2}{|c|}{$\begin{array}{l}\mathrm{ns} \\
1.0\end{array}$}} & \multirow{2}{*}{\multicolumn{2}{|c|}{$\begin{array}{l}\text { ns } \\
10.6\end{array}$}} & \multirow{2}{*}{\multicolumn{2}{|c|}{$\begin{array}{l}\text { ns } \\
2.0\end{array}$}} & \multirow{2}{*}{\multicolumn{2}{|c|}{$\begin{array}{l}\text { ns } \\
8.5\end{array}$}} & \multirow{2}{*}{\multicolumn{2}{|c|}{$\begin{array}{l}\text { ns } \\
2.9\end{array}$}} & \multirow{2}{*}{\multicolumn{2}{|c|}{$\begin{array}{l}\text { ns } \\
8.3\end{array}$}} \\
\hline $\operatorname{LSD}(P<0.05)$ & & & & & & & & & & & & & & \\
\hline
\end{tabular}

(b) Stem morphology

\begin{tabular}{ll}
$\begin{array}{l}\text { Stem diameter } \\
(\mathrm{mm})\end{array}$ \\
\hline 32 & 22 \\
${ }^{\circ} \mathrm{C}$ & ${ }^{\circ} \mathrm{C}$
\end{tabular}

$\begin{aligned} & \text { Average area per } \\ & \text { vascular bundle }\left(\mu \mathrm{m}^{2}\right)\end{aligned}$
$\begin{array}{lc}32 & 22 \\ { }^{\circ} \mathrm{C} & { }^{\circ} \mathrm{C}\end{array}$

1.4

5717

3504

2309

na

M. laxum

Mean

$1.5^{*}$
1.4

2.5

1.7

\begin{tabular}{ll}
$\begin{array}{l}\text { Number of vascular } \\
\text { bundles }\end{array}$ \\
\hline 32 & 22 \\
${ }^{\circ} \mathrm{C}$ & ${ }^{\circ} \mathrm{C}$
\end{tabular}

\section{0}

5121

3381

na

4884

\section{8}

52

37

na

42

44

37
56
40
na
44

ns

1212 ns

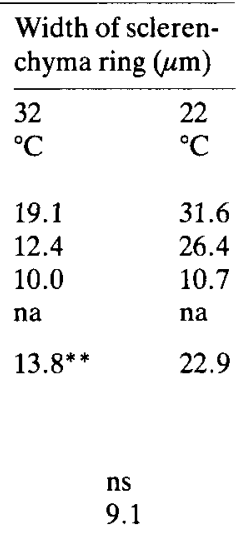

${ }^{1} \mathrm{CHL}=$ chlorenchyma in cortex, EPI $=$ epidermis, $\mathrm{PAR}=$ parenchyma pith cells, $\mathrm{PHL}=$ phloem, VAS $=$ lignified vascular tissue, $\mathrm{SCL}=$ lignified sclerenchyma ring in grasses and pericyle in $M$. sativa. Not included for $M$. sativa is collenchyma, $10.1\left(32^{\circ} \mathrm{C}\right)$ and $12.5\left(22^{\circ} \mathrm{C}\right)$.

${ }^{2}$ Total lignified tissues.

na $=$ not applicable.

$\mathrm{ns}=$ not significant; ${ }^{*}, P<0.05 ;{ }^{* *}, P<0.01$. 
Table 5. Average thickness $(\mu \mathrm{m}) \pm$ standard errors of cell walls of the metaxylem vessels and sclerenchyma cells in leaf and stem tissues from plants grown at different temperatures.

\begin{tabular}{|c|c|c|c|c|c|c|c|c|}
\hline \multirow[t]{3}{*}{ Species } & \multicolumn{4}{|c|}{ Leaf blade } & \multicolumn{4}{|l|}{ Stem } \\
\hline & \multicolumn{2}{|c|}{ metaxylem } & \multicolumn{2}{|c|}{ sclerenchyma } & \multicolumn{2}{|c|}{ metaxylem } & \multicolumn{2}{|c|}{ sclerenchyma } \\
\hline & $32{ }^{\circ} \mathrm{C}$ & $22^{\circ} \mathrm{C}$ & $32{ }^{\circ} \mathrm{C}$ & $22^{\circ} \mathrm{C}$ & $32^{\circ} \mathrm{C}$ & $22^{\circ} \mathrm{C}$ & $32{ }^{\circ} \mathrm{C}$ & $22^{\circ} \mathrm{C}$ \\
\hline C. dactylon & $\begin{array}{r}0.85 \\
\pm 0.03\end{array}$ & $\begin{array}{c}0.69^{* *} \\
\pm 0.02\end{array}$ & $\begin{array}{r}0.99 \\
\pm 0.02\end{array}$ & $\begin{array}{c}0.87^{*} \\
\pm 0.02\end{array}$ & $\begin{array}{r}1.08 \\
\pm 0.02\end{array}$ & $\begin{array}{r}1.01 \\
\pm 0.02\end{array}$ & $\begin{array}{r}1.67 \\
\pm 0.04\end{array}$ & $\begin{array}{l}1.40^{* *} \\
\pm 0.03\end{array}$ \\
\hline$P$. maximum & $\begin{array}{r}0.90 \\
\pm 0.02\end{array}$ & $\begin{array}{l}1.03^{* *} \\
\pm 0.02\end{array}$ & $\begin{array}{r}1.21 \\
\pm 0.03\end{array}$ & $\begin{array}{c}1.43^{*} \\
\pm 0.04\end{array}$ & $\begin{array}{r}0.78 \\
\pm 0.01\end{array}$ & $\begin{array}{c}0.83^{*} \\
\pm 0.01\end{array}$ & $\begin{array}{r}1.56 \\
\pm 0.04\end{array}$ & $\begin{aligned} & 2.85^{* * *} \\
\pm & 0.05\end{aligned}$ \\
\hline P. laxum & $\begin{array}{r}0.75 \\
\pm 0.02\end{array}$ & $\begin{array}{c}0.84^{*} \\
\pm 0.02\end{array}$ & $\begin{array}{r}1.01 \\
\pm 0.02\end{array}$ & $\begin{array}{l}1.12^{*} \\
\pm 0.03\end{array}$ & $\begin{array}{r}0.65 \\
\pm 0.01\end{array}$ & $\begin{array}{c}0.74^{* *} \\
\pm 0.01\end{array}$ & $\begin{array}{r}1.72 \\
\pm 0.03\end{array}$ & $\begin{array}{l}1.55^{*} \\
\pm 0.03\end{array}$ \\
\hline L. perenne & $\begin{array}{r}0.92 \\
\pm 0.03\end{array}$ & $\begin{array}{r}0.90 \\
\pm 0.02\end{array}$ & $\begin{array}{r}1.00 \\
\pm 0.02\end{array}$ & $\begin{array}{r}0.97 \\
\pm 0.02\end{array}$ & $\mathrm{np}$ & np & $\mathrm{np}$ & $\mathrm{np}$ \\
\hline$M$. sativa & $\begin{array}{r}1.68 \\
\pm 0.05\end{array}$ & $\begin{array}{r}1.68 \\
\pm 0.07\end{array}$ & na & na & $\begin{array}{r}1.66 \\
\pm 0.03\end{array}$ & $\begin{array}{l}1.45^{* *} \\
\pm 0.02\end{array}$ & na & na \\
\hline
\end{tabular}

$\mathrm{np}=$ not present $; \mathrm{na}=$ not applicable.

Significant differences between temperature treatments are indicated: ${ }^{*} P<0.05 ;{ }^{* *} P<0.01 ;{ }^{* * *} P<$ 0.001 .

Wall thickness of metaxylem and sclerenchyma. Significant effects of temperature and differences in species response were observed (Table 5). Wall thickness of both cell types was generally increased by higher temperature in $C$. dactylon but decreased in $P$. maximum and $P$. laxum. In $L$. perenne and $M$. sativa, temperature had no effect on wall thickness except for an increase in value at $32{ }^{\circ} \mathrm{C}$ for metaxylem in M. sativa stem.

Staining of lignified cell walls. Acid-phloroglucinol staining was more intense for the vascular tissue than the sclerenchyma, and in the latter tissue, $C$. dactylon, $P$. lax$u m$ and $L$. perenne showed no visible colour reaction at all in the leaf blade at either temperature (Table 6). Chlorine sulphite gave a stronger staining reaction with sclerenchyma than did acid-phloroglucinol (Table 6), especially in the leaf blade. However, it tended to be weaker than for acid-phloroglucinol in the vascular tissue, particularly for $M$. sativa.

Generally, there was not a strong difference in staining between the temperature treatments with either acid-phloroglucinol or chlorine sulphite, only $P$. maximum showed a consistent tendency towards greater staining at $32{ }^{\circ} \mathrm{C}$ than at $22{ }^{\circ} \mathrm{C}$ in both the vascular and sclerenchyma cell walls.

\section{Digestion of different cell types}

In the leaf blade the observed extent of digestion generally increased progressively 
Table 6. Estimated intensity of staining ${ }^{1}$ of lignified cell walls by acid phloroglucinol and chlorine sulphite of leaf and stem grown at different temeratures.

\begin{tabular}{|c|c|c|c|c|}
\hline \multirow{3}{*}{$\begin{array}{l}\text { Species and } \\
\text { plant part }\end{array}$} & \multicolumn{2}{|c|}{ Acid-phloroglucinol } & \multicolumn{2}{|c|}{ Chlorine sulphite } \\
\hline & VAS $^{2}$ & SCL & VAS & SCL \\
\hline & $32^{\circ} \mathrm{C}$ & $32{ }^{\circ} \mathrm{C}$ & $32{ }^{\circ} \mathrm{C}$ & $32{ }^{\circ} \mathrm{C}$ \\
\hline
\end{tabular}

Leaf blade

C. dactylon

$P$. maximum

P. laxum

L. perenne

M. sativa

$\begin{array}{llllllll}1.6 & 1.1 & 0 & 0 & 1.5 & 1.0 & 0.7 & 0.6 \\ 2.7 & 2.0 & 1.2 & 0.7 & 2.0 & 1.3 & 1.8 & 1.5 \\ 0.7 & 1.3 & 0 & 0 & 1.3 & 2.0 & 0.8 & 1.2 \\ 1.3 & 1.8 & 0 & 0 & 1.7 & 1.0 & 2.0 & 1.3 \\ 2.7 & 2.7 & \text { np } & \text { np } & 0.3 & 0.2 & \text { np } & \text { np }\end{array}$

Temperature $\times$ species interaction $\mathrm{LSD}(P<0.05)$

\section{Stem}

C. dactylon

$3.0 \quad 3.0$

\section{3}

2.3
1.5
0.4
$\mathrm{np}$

\section{0}

\section{0}

\section{8}

2.5

1.8

1.3

1.7

2.7

2.7

np

${ }^{1}$ Rated on a scale of $0-4$.

2 VAS $=$ vascular tissue, $\mathrm{SCL}=$ sclerenchyma.

nd $=$ not determined; $\mathrm{np}=$ not present .

with longer time in rumen fluid and was generally most pronounced for the parenchyma of the midrib, the mesophyll and the epidermal cells (Table 7). These tissues also showed little difference in digestion between temperature treatments, with perhaps the exception of the epidermal cells in P. laxum. The less digestible tissues (bundle sheath, vascular and sclerenchyma cells) were more slowly and less digested at $32{ }^{\circ} \mathrm{C}$ than at $22{ }^{\circ} \mathrm{C}$ in all the grasses. The temperature response was particularly strong for the sclerenchyma cells in all grasses, and the bundle sheath cells in $C$. dactylon, $P$. laxum and $L$. perenne. Loss of vascular tissue by digestion was less than for other tissues and a pronounced effect of higher temperature on slower digestion was apparent only for $L$. perenne which showed a reasonable amount of digestion at $22^{\circ} \mathrm{C}$.

In the stem, only the pith parenchyma cells digested to any great extent, and only in $P$. laxum was there a temperature effect with digestion being less at $32{ }^{\circ} \mathrm{C}$ than at $22{ }^{\circ} \mathrm{C}$ (Table 8). Most of the parenchyma tissue disappeared in the first $10 \mathrm{~h}$ of digestion. The other tissues mostly showed little digestion as measured by loss of cell tissue from the sections on the microscope slides, and no consistent effect of temperature on their digestion.

However, closer examination of the walls of individual cells of metaxylem vessels 
Table 7. Percentage digestion of cell types for leaves grown at different temperatures, estimated as the disappearance of tissue in $100 \mu \mathrm{m}$ transverse sections on microscope slides immersed in rumen fluid for 10, 24 and 48 hours.

\begin{tabular}{|c|c|c|c|c|c|c|c|c|c|c|c|c|c|c|c|c|c|}
\hline & \multirow{3}{*}{$\begin{array}{l}\text { Time } \\
\text { of } \\
\text { diges- } \\
\text { tion } \\
\text { (h) }\end{array}$} & \multicolumn{6}{|c|}{ Leaf blade } & \multicolumn{4}{|c|}{$\begin{array}{l}\text { Main vascular } \\
\text { bundles }\end{array}$} & \multicolumn{6}{|c|}{ Midrib } \\
\hline & & \multicolumn{2}{|c|}{$\mathrm{MES}^{1}$} & \multicolumn{2}{|l|}{ BS } & \multicolumn{2}{|c|}{ EPI } & \multicolumn{2}{|c|}{ VAS } & \multicolumn{2}{|c|}{ SCL } & \multicolumn{2}{|c|}{ PAR } & \multicolumn{2}{|c|}{ VAS } & \multicolumn{2}{|c|}{ SCL } \\
\hline & & $\begin{array}{l}32 \\
{ }^{\circ} \mathrm{C}\end{array}$ & $\begin{array}{l}22 \\
{ }^{\circ} \mathrm{C}\end{array}$ & $\begin{array}{l}32 \\
{ }^{\circ} \mathrm{C}\end{array}$ & $\begin{array}{l}22 \\
{ }^{\circ} \mathrm{C}\end{array}$ & $\begin{array}{l}32 \\
{ }^{\circ} \mathrm{C}\end{array}$ & $\begin{array}{l}22 \\
{ }^{\circ} \mathrm{C}\end{array}$ & $\begin{array}{l}32 \\
{ }^{\circ} \mathrm{C}\end{array}$ & $\begin{array}{l}22 \\
{ }^{\circ} \mathrm{C}\end{array}$ & $\begin{array}{l}32 \\
{ }^{\circ} \mathrm{C}\end{array}$ & $\begin{array}{l}22 \\
{ }^{\circ} \mathrm{C}\end{array}$ & $\begin{array}{l}32 \\
{ }^{\circ} \mathrm{C}\end{array}$ & $\begin{array}{l}22 \\
{ }^{\circ} \mathrm{C}\end{array}$ & $\begin{array}{l}32 \\
{ }^{\circ} \mathrm{C}\end{array}$ & $\begin{array}{l}22 \\
{ }^{\circ} \mathrm{C}\end{array}$ & $\begin{array}{l}32 \\
{ }^{\circ} \mathrm{C}\end{array}$ & $\begin{array}{l}22 \\
{ }^{\circ} \mathrm{C}\end{array}$ \\
\hline C. dactylon & $\begin{array}{l}10 \\
24 \\
48\end{array}$ & $\begin{array}{l}22 \\
52 \\
60\end{array}$ & $\begin{array}{l}29 \\
32 \\
52\end{array}$ & $\begin{array}{l}0 \\
0 \\
5\end{array}$ & $\begin{array}{r}0 \\
15 \\
47\end{array}$ & $\begin{array}{l}17 \\
70 \\
68\end{array}$ & $\begin{array}{l}22 \\
75 \\
68\end{array}$ & $\begin{array}{l}0 \\
4 \\
4\end{array}$ & $\begin{array}{r}0 \\
12 \\
14\end{array}$ & $\begin{array}{r}0 \\
82 \\
72\end{array}$ & $\begin{array}{r}0 \\
93 \\
95\end{array}$ & $\begin{array}{l}\text { np } \\
\text { np } \\
\text { np }\end{array}$ & $\begin{array}{l}\text { np } \\
\text { np } \\
\text { np }\end{array}$ & $\begin{array}{l}0 \\
6 \\
2\end{array}$ & $\begin{array}{r}0 \\
10 \\
8\end{array}$ & $\begin{array}{r}0 \\
58 \\
54\end{array}$ & $\begin{array}{r}0 \\
92 \\
95\end{array}$ \\
\hline$P$. maximum & $\begin{array}{l}10 \\
24 \\
48\end{array}$ & $\begin{array}{l}48 \\
76 \\
92\end{array}$ & $\begin{array}{l}48 \\
72 \\
89\end{array}$ & $\begin{array}{r}0 \\
31 \\
60\end{array}$ & $\begin{array}{r}0 \\
45 \\
63\end{array}$ & $\begin{array}{l}20 \\
80 \\
93\end{array}$ & $\begin{array}{l}25 \\
90 \\
91\end{array}$ & $\begin{array}{l}0 \\
6 \\
6\end{array}$ & $\begin{array}{r}0 \\
12 \\
8\end{array}$ & $\begin{array}{r}0 \\
22 \\
48\end{array}$ & $\begin{array}{r}0 \\
68 \\
67\end{array}$ & $\begin{array}{r}20 \\
100 \\
100\end{array}$ & $\begin{array}{r}88 \\
100 \\
100\end{array}$ & $\begin{array}{l}0 \\
5 \\
4\end{array}$ & $\begin{array}{l}0 \\
8 \\
8\end{array}$ & $\begin{array}{l}0 \\
0 \\
0\end{array}$ & $\begin{array}{r}0 \\
20 \\
23\end{array}$ \\
\hline P. laxum & $\begin{array}{l}10 \\
24 \\
48\end{array}$ & $\begin{array}{l}12 \\
31 \\
57\end{array}$ & $\begin{array}{l}28 \\
32 \\
48\end{array}$ & $\begin{array}{l}0 \\
8 \\
7\end{array}$ & $\begin{array}{r}0 \\
42 \\
43\end{array}$ & $\begin{array}{r}0 \\
30 \\
20\end{array}$ & $\begin{array}{r}0 \\
45 \\
49\end{array}$ & $\begin{array}{l}0 \\
3 \\
0\end{array}$ & $\begin{array}{l}0 \\
4 \\
0\end{array}$ & $\begin{array}{r}0 \\
11 \\
28\end{array}$ & $\begin{array}{r}0 \\
23 \\
25\end{array}$ & $\begin{array}{l}\text { np } \\
\text { np } \\
\text { np }\end{array}$ & $\begin{array}{l}\text { np } \\
\text { np } \\
\text { np }\end{array}$ & $\begin{array}{l}0 \\
3 \\
3\end{array}$ & $\begin{array}{l}0 \\
5 \\
0\end{array}$ & $\begin{array}{l}0 \\
3 \\
0\end{array}$ & $\begin{array}{r}0 \\
11 \\
12\end{array}$ \\
\hline L. perenne & $\begin{array}{l}10 \\
24 \\
48\end{array}$ & $\begin{array}{l}38 \\
48 \\
85\end{array}$ & $\begin{array}{l}62 \\
52 \\
88\end{array}$ & $\begin{array}{r}0 \\
10 \\
17\end{array}$ & $\begin{array}{r}0 \\
55 \\
68\end{array}$ & $\begin{array}{r}1 \\
63 \\
58\end{array}$ & $\begin{array}{l}30 \\
59 \\
78\end{array}$ & $\begin{array}{l}0 \\
2 \\
8\end{array}$ & $\begin{array}{r}0 \\
26 \\
39\end{array}$ & $\begin{array}{r}0 \\
10 \\
48\end{array}$ & $\begin{array}{r}0 \\
96 \\
100\end{array}$ & $\begin{array}{l}\text { np } \\
\text { np } \\
\text { np }\end{array}$ & $\begin{array}{l}\text { np } \\
\text { np } \\
\text { np }\end{array}$ & $\begin{array}{r}0 \\
5 \\
12\end{array}$ & $\begin{array}{r}0 \\
15 \\
40\end{array}$ & $\begin{array}{r}0 \\
5 \\
30\end{array}$ & $\begin{array}{r}0 \\
59 \\
89\end{array}$ \\
\hline M. sativa & $\begin{array}{l}10 \\
24 \\
48\end{array}$ & $\begin{array}{l}68 \\
33 \\
63\end{array}$ & $\begin{array}{l}92 \\
48 \\
48\end{array}$ & $\begin{array}{l}\text { na } \\
\text { na } \\
\text { na }\end{array}$ & $\begin{array}{l}\text { na } \\
\text { na } \\
\text { na }\end{array}$ & $\begin{array}{l}\text { nd } \\
\text { nd } \\
\text { nd }\end{array}$ & $\begin{array}{l}\text { nd } \\
\text { nd } \\
\text { nd }\end{array}$ & $\begin{array}{l}\text { nd } \\
\text { nd } \\
\text { nd }\end{array}$ & $\begin{array}{l}\text { nd } \\
\text { nd } \\
\text { nd }\end{array}$ & $\begin{array}{l}\text { na } \\
\text { na } \\
\text { na }\end{array}$ & $\begin{array}{l}\text { na } \\
\text { na } \\
\text { na }\end{array}$ & $\begin{array}{r}87 \\
100 \\
98\end{array}$ & $\begin{array}{r}100 \\
98 \\
93\end{array}$ & $\begin{array}{l}0 \\
0 \\
0\end{array}$ & $\begin{array}{l}0 \\
0 \\
0\end{array}$ & $\begin{array}{l}\text { np } \\
\text { np } \\
\text { np }\end{array}$ & $\begin{array}{l}n p \\
n p \\
n p\end{array}$ \\
\hline
\end{tabular}

Analysis of angular transform values

Temperature effect

Temperature $x$

spp. interaction ns

ns ns

ns nd

nd

${ }^{1}$ MES = mesophyll, BS = parenchyma bundle sheath, EPI $=$ epidermis, $\mathrm{SCL}=$ sclerenchyma, $\mathrm{PAR}=$ parenchyma. $\mathrm{np}=$ not present $; \mathrm{nd}=$ not determined; $\mathrm{na}=$ not applicable.

ns $=$ not significant $;{ }^{*} P<0.05 ;{ }^{* *} P<0.001$.

and sclerenchyma in the stem tissue at high magnification revealed quite extensive digestion and reduction in thickness of these walls in all the grasses but not in $M$. sativa (Table 9). In the grasses, the percent reduction in wall thickness ranged from 13-32 \% for the metaxylem vessels and from 54-85\% for the sclerenchyma cells. In the latter cells, the extent of digestion appeared to be less at $32{ }^{\circ} \mathrm{C}$ than at $22{ }^{\circ} \mathrm{C}$ in $C$. dactylon and $P$. maximum, with a suggestion of a similar trend in the metaxylem.

The extent of digestion of vascular and sclerenchyma cell walls is illustrated in Figure 2 comparing identical cells in the undigested and 48-hour-digested sections for $P$. maximum grown at $32{ }^{\circ} \mathrm{C}$ and $22{ }^{\circ} \mathrm{C}$. Note that these cell wall thicknesses may differ from those in Table 5 because this was a small sample of matched cells in one or two positions within the stem, and not a large sample of cells from many positions in the stem as shown in Table 5. The control leaf and stem sections incubated for 48 hours in killed rumen fluid/buffer showed no loss of any cell tissues. 
Table 8. Percentage digestion of cell types for stem grown at different temperatures, estimated as the disappearance of tissue in $100 \mu \mathrm{m}$ transverse sections on microscope slides immersed in rumen fluid for 10,24 and 48 hours.

\begin{tabular}{|c|c|c|c|c|c|c|c|c|c|c|c|}
\hline \multirow[t]{2}{*}{ Species } & \multirow{2}{*}{$\begin{array}{l}\text { Time of } \\
\text { diges- } \\
\text { tion (h) }\end{array}$} & \multicolumn{2}{|l|}{$\mathrm{EPI}^{1}$} & \multicolumn{2}{|l|}{$\mathrm{CHL}$} & \multicolumn{2}{|l|}{ SCL } & \multicolumn{2}{|l|}{ VAS } & \multicolumn{2}{|l|}{ PAR } \\
\hline & & $32^{\circ} \mathrm{C}$ & $22^{\circ} \mathrm{C}$ & $32^{\circ} \mathrm{C}$ & $22^{\circ} \mathrm{C}$ & $32^{\circ} \mathrm{C}$ & $22^{\circ} \mathrm{C}$ & $32{ }^{\circ} \mathrm{C}$ & $22^{\circ} \mathrm{C}$ & $32^{\circ} \mathrm{C}$ & $22^{\circ} \mathrm{C}$ \\
\hline \multirow[t]{3}{*}{ C. dactylon } & 10 & 0 & 0 & 0 & 0 & 0 & 0 & 0 & 0 & 73 & 92 \\
\hline & 24 & 0 & 0 & 0 & 0 & 0 & 0 & 0 & 5 & 90 & 100 \\
\hline & 48 & 0 & 0 & 0 & 0 & 0 & 0 & 0 & 3 & 97 & 100 \\
\hline \multirow[t]{3}{*}{ P. maximum } & 10 & 0 & 0 & 3 & 35 & 0 & 0 & 0 & 0 & 97 & 90 \\
\hline & 24 & 7 & 0 & 47 & 20 & 0 & 0 & 1 & 0 & 100 & 80 \\
\hline & 48 & 7 & 0 & 37 & 10 & 0 & 0 & 3 & 0 & 99 & 90 \\
\hline \multirow[t]{3}{*}{ P. laxum } & 10 & 0 & 0 & 3 & 5 & 0 & 0 & 0 & 0 & 52 & 90 \\
\hline & 24 & 10 & 15 & 13 & 15 & 0 & 0 & 0 & 0 & 57 & 100 \\
\hline & 48 & 10 & 7 & 15 & 15 & 0 & 0 & 0 & 0 & 77 & 98 \\
\hline \multirow[t]{3}{*}{$M$. sativa } & 10 & 85 & 70 & 30 & 10 & - & - & 0 & 0 & 92 & 90 \\
\hline & 24 & 52 & 57 & 25 & 10 & - & - & 0 & 0 & 100 & 90 \\
\hline & 48 & 90 & 30 & 30 & 10 & - & - & 0 & 0 & 98 & 97 \\
\hline \multicolumn{12}{|c|}{ Analysis of angular transform values } \\
\hline \multicolumn{2}{|c|}{ Temperature effect } & \multirow{2}{*}{\multicolumn{2}{|c|}{$\begin{array}{l}\text { ns } \\
\text { ns }\end{array}$}} & \multicolumn{2}{|l|}{ ns } & \multicolumn{2}{|l|}{ nd } & \multicolumn{2}{|l|}{ nd } & \multicolumn{2}{|l|}{ ns } \\
\hline \multicolumn{2}{|c|}{ Temperature $\times$ species effect } & & & \multicolumn{2}{|l|}{ ns } & \multicolumn{2}{|l|}{ nd } & \multicolumn{2}{|l|}{ nd } & \multicolumn{2}{|l|}{$* *$} \\
\hline
\end{tabular}

${ }^{1} \mathrm{EPI}=$ epidermis, $\mathrm{CHL}=$ chlorenchyma, $\mathrm{SCL}=$ sclerenchyma ring in grasses, $\mathrm{VAS}=$ vascular bundles, PAR = parenchyma pith cells in centre of stem.

nd $=$ not determined; $\mathrm{ns}=$ not significant, ${ }^{* *} P<0.01$.

Table 9. Digestion after 48 hours in rumen fluid of cell walls of metaxylem vessels and sclerenchyma cells in stems from plants grown at different temperatures. Expressed as the percentage reduction in wall thickness from comparison of identical cells in the control and digested treatments using serial sections from the same piece of stem.

\begin{tabular}{|c|c|c|c|c|c|c|}
\hline \multirow{3}{*}{$\begin{array}{l}\text { Species and } \\
\text { cell type }\end{array}$} & \multicolumn{3}{|l|}{$32^{\circ} \mathrm{C}$} & \multicolumn{3}{|l|}{$22{ }^{\circ} \mathrm{C}$} \\
\hline & \multicolumn{2}{|c|}{ wall thickness $(\mu \mathrm{m})$} & \multirow{2}{*}{$\begin{array}{l}\text { reduction in } \\
\text { thickness } \\
(\%)^{1}\end{array}$} & \multicolumn{2}{|c|}{ wall thickness $(\mu \mathrm{m})$} & \multirow{2}{*}{$\begin{array}{l}\text { reduction in } \\
\text { thickness } \\
(\%)^{1}\end{array}$} \\
\hline & undigested & $\begin{array}{l}\text { digested } \\
48 \mathrm{~h}\end{array}$ & & undigested & $\begin{array}{l}\text { digested } \\
48 \mathrm{~h}\end{array}$ & \\
\hline \multicolumn{7}{|c|}{ Metaxylem vessels } \\
\hline $\begin{array}{l}\text { C. dactylon } \\
P . \text { maximum } \\
P . \text { laxum } \\
M . \text { sativa }\end{array}$ & $\begin{array}{l}0.78 \pm 0.02 \\
0.63 \pm 0.01 \\
0.54 \pm 0.01 \\
1.07 \pm 0.02\end{array}$ & $\begin{array}{l}0.68 \pm 0.01 \\
0.50 \pm 0.01 \\
0.37 \pm 0.01 \\
1.06 \pm 0.05\end{array}$ & $\begin{array}{r}13.0 \\
19.4 \\
31.6 \\
0.6\end{array}$ & $\begin{array}{l}0.69 \pm 0.02 \\
0.72 \pm 0.01 \\
0.57 \pm 0.01 \\
1.39 \pm 0.04\end{array}$ & $\begin{array}{l}0.59 \pm 0.01 \\
0.50 \pm 0.01 \\
0.42 \pm 0.01 \\
1.38 \pm 0.03\end{array}$ & $\begin{array}{r}14.5 \\
28.4 \\
24.3 \\
0.8\end{array}$ \\
\hline \multicolumn{7}{|c|}{ Sclerenchyma cells } \\
\hline $\begin{array}{l}\text { C. dactylon } \\
\text { P. maximum } \\
\text { P. laxum }\end{array}$ & $\begin{array}{l}2.04 \pm 0.07 \\
1.61 \pm 0.06 \\
1.44 \pm 0.04\end{array}$ & $\begin{array}{l}0.92 \pm 0.03 \\
0.59 \pm 0.04 \\
0.41 \pm 0.01\end{array}$ & $\begin{array}{l}53.7 \\
61.9 \\
71.2\end{array}$ & $\begin{array}{l}2.03 \pm 0.06 \\
3.17 \pm 0.04 \\
1.56 \pm 0.06\end{array}$ & $\begin{array}{l}0.65 \pm 0.02 \\
0.46 \pm 0.02 \\
0.43 \pm 0.01\end{array}$ & $\begin{array}{l}68.0 \\
85.4 \\
71.3\end{array}$ \\
\hline
\end{tabular}

${ }^{1}$ The LSD $(P<0.05)$ for comparison of species $\times$ temperature means for reduction in wall thickness is: metaxylem 18.6, sclerenchyma 10.2 . 

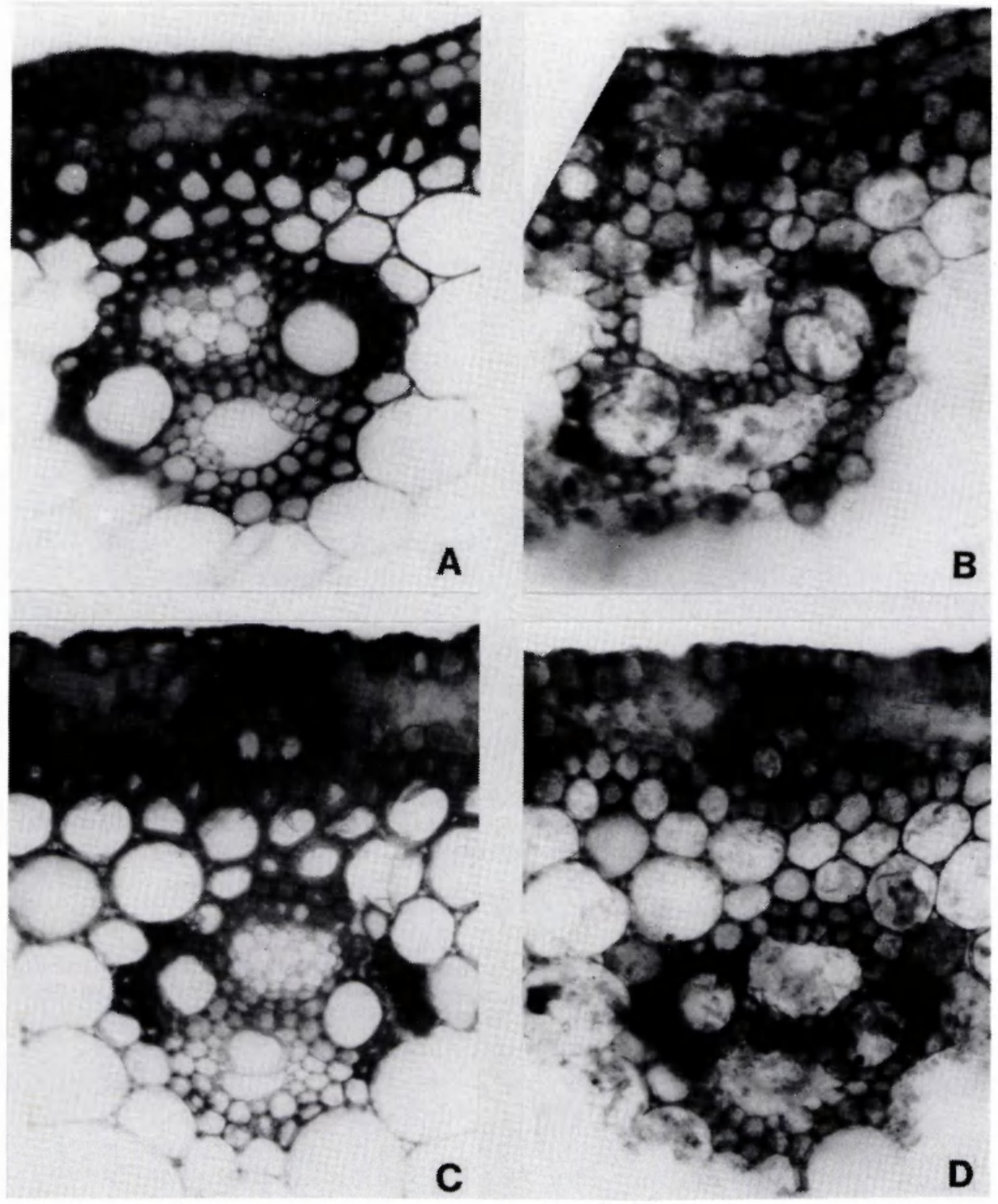

Fig. 2. Light photomicrographs $(\times 250)$ showing the extent of digestion of vascular bundle and sclerenchyma walls by comparing identical cells in undigested control and 48-hour-digested stem sections of $P$. maximum grown at either high or low temperature. (A) $32 / 26{ }^{\circ} \mathrm{C}$, control; (B) $32 / 26{ }^{\circ} \mathrm{C}$, digested; (C) $22 / 16{ }^{\circ} \mathrm{C}$, control; (D) $22 / 16^{\circ} \mathrm{C}$, digested. 


\section{Discussion}

The decrease in OMD with higher growth temperature in this experiment, averaging 6.6 and $12.4 \%$ units for the grass bulk leaf and stem fractions, respectively, and $2.6 \%$ units for $M$. sativa leaf and stem, was in line with the average effect determined over a large number of experiments in Wilson (1982). The consistently lower OMD at $32{ }^{\circ} \mathrm{C}$ than at $22{ }^{\circ} \mathrm{C}$ was poorly related to the changes in cell wall content which were relatively small, and variable in direction.

Similarly, there was no consistent effect of high temperature on increasing the thickness of cell walls of the major lignified tissues, the xylem and sclerenchyma. This did occur in $C$. dactylon, but in $P$. maximum and $P$. laxum the opposite result was obtained. The extensive studies of tracheid development in trees (e.g. Denne, 1971; Jenkins, 1975) suggests that wall thicknesses are greater when rates of tissue development are slower (usually at lower temperatures), which could explain the results for $P$. maximum and $P$. laxum, but not those for $C$. dactylon. In these three tropical species, leaf development was much slower at $22^{\circ} \mathrm{C}$ than at $32{ }^{\circ} \mathrm{C}$. The temperature species, $L$. perenne and $M$. sativa, had slower leaf development at higher temperature and there was perhaps a slight tendency for cell wall thickness to be greater at $32{ }^{\circ} \mathrm{C}$ than $22^{\circ} \mathrm{C}$.

Differences in gross anatomical structure of leaf or stem between high and low temperature treatments also did not explain the temperature effect on OMD. The relative proportions of the different tissues were largely unaltered by growth temperature in the leaf blade, but there was a small increase in the percentage of the lignified, less digestible vascular and sclerenchyma tissue in the midrib at $32{ }^{\circ} \mathrm{C}$. In the stem, the alterations, viz. a decrease in \% total lignified tissue, average vascular bundle size and the width of the sclerenchyma ring at $32{ }^{\circ} \mathrm{C}$, should have contributed to an increase in OMD at this temperature, not a decrease as was found. These results for a suite of species with different types of anatomy, and their agreement with Akin et al. (1987) and Da Silva et al. (1987), strongly indicate a general proposition that temperature effects on leaf or stem structure are small and not a significant factor in the consistent temperature-induced differences in forage digestibility.

The major effect of high temperature on OMD clearly resided in the increased lignin content at $32{ }^{\circ} \mathrm{C}$ which reduced digestibility of the cell walls in both leaf and stem. The lack of a general increase in the proportion of lignified tissues in leaf and stem, and the variable response of cell wall thickness to temperature, further indicate that the effect was almost entirely due to an increase in the concentration of lignin in the walls of normally lignified cells. The microscopic examination of the thin sections confirmed that reduced digestion was most apparent for the generally less digestible and lignified tissue types of cells within the leaf. These cells were more slowly and less completely digested at $32{ }^{\circ} \mathrm{C}$ than at $22{ }^{\circ} \mathrm{C}$. Estimates of digestion using the slide technique are based on loss of whole cells or complete loss of sections of their walls. Thus the technique is not sensitive for the vascular and sclerenchyma tissues in stem in which no digestion was recorded for either temperature treatment (Table 8), because these tissues maintained their integrity and cells or complete portions of walls were not lost from the section. However, it is quite apparent from 
examination at high magnification that there was considerable digestion of the walls in these cell types (cf. Table 9) and that, for the stem sclerenchyma it was clearly less at $32{ }^{\circ} \mathrm{C}$ than at $22{ }^{\circ} \mathrm{C}$ in $P$. maximum and $C$. dactylon. For the more digestible tissues (mesophyll, epidermis and parenchyma in the leaf, and parenchyma in the stem), there is a suggestion that the initial digestion within 10 hours was slower for tissues grown at $32^{\circ} \mathrm{C}$, but this difference was not reflected in the final extent of digestion at 48 hours. These data on the relative effects of temperature on the digestibility of different cell types in the leaf generally agree with those of Akin et al. (1987) for tall fescue, the only other study of this type found in the literature.

Despite the strong effects of growth temperature on the concentration of lignin in the cell walls, the changes in the intensity of staining of the xylem and sclerenchyma cell walls in leaf and stem with acid-phloroglucinol and chlorine sulphite were slight and inconsistent for most of the species. Only P. maximum showed a general tendency towards more intense staining at $32{ }^{\circ} \mathrm{C}$. Akin et al. (1987) similarly found no marked effect of temperature on the reaction of these stains in tall fescue. Engels (1989) and Cone \& Engels (1990) reported variable results in maize, with chlorine sulphite staining lignified walls more intensively in plants grown at $30 / 24{ }^{\circ} \mathrm{C}$ than at $18 / 12{ }^{\circ} \mathrm{C}$, but conversely for the acid-phloroglucinol staining. The latter reaction did not match with the much lower digestibility of the maize at high temperature (Struik et al., 1985). Staining intensity thus appears to be an insensitive indicator of treatment effect.

The substantial reduction in wall thickness through digestion of stem metaxylem vessel (13-32 \%) and sclerenchyma cells (54-85\%) in the grasses raises a point of wider interest to evaluation of tissue digestibility because these cells are often reported as totally resistant to degradation by rumen microorganisms (e.g. Akin, 1986). The stems in this work were mature and the cells stained with acid-phloroglucinol suggesting strong lignification. Although, in $P$. maximum at $22^{\circ} \mathrm{C}$ the secondary wall of the sclerenchyma was rather less stained than the primary wall and the middle lamella. It was always the secondary wall of these cells that was digested and the primary wall and middle lamella remained; Engels (1989) reported similar results for sclerenchyma in maize stems, which also stained strongly with acid-phloroglucinol suggesting intense lignification. He found this staining propensity was removed from the secondary wall (but not the primary wall) by $\mathrm{KMnO}_{4}$ or $\mathrm{NaOH}$ pretreatment. The secondary wall thus had a largely soluble 'lignin' component which did not hinder digestion. Another possible factor of importance is that the cells examined were at the cut surface of the stem segment and thus the rumen microorganisms had immediate access to the cell wall. Chesson et al. (1986) with digestion studies on isolated fibre strands from ryegrass reported $40 \%$ loss of dry matter from heavily lignified cell walls. Thus the apparently resistent nature of xylem vessels and sclerenchyma fibres, even after very long periods of digestion (e.g. Wilson et al., 1989), may be as much associated with inability of organisms to gain access to the cell wall away from the cut surface because of the bundle structures, as with the actual indegradability of the wall itself. This would be especially so in the stem because of the solid structure of the sclerenchyma ring. 


\section{Conclusions}

Effects of growth temperature do not appear to be associated with modification of anatomical structure of leaf and stem assessed as changes in the proportion of different cell types. This was so for all the species despite their different types of anatomy. Nor was the decrease in digestibility at high temperature generally associated with an increased thickness of the secondary walls of the less digestible types of cells, in fact thicker walls occurred at the lower temperature in two of the grasses. However, a lesser degree of digestion of vascular, sclerenchyma and bundle sheath cells was clearly evident for plants grown at the higher temperature. This is in agreement with the effect of growth temperature being mainly on lignin content of the tissues which was increased substantially at high temperature and was highly correlated with the decrease in organic matter digestibility. Since anatomical structure of leaf and stem was little affected, it can be presumed that the effect of high temperature operated through an increased intensity of lignification of the existing lignified cell walls. Staining intensity was an insensitive indicator of this change.

\section{Acknowledgements}

We would like to thank the Department of 'Tropical Agriculture, Agricultural University, Wageningen, for provision of temperature-controlled glasshouse space and for help in looking after the plants. Also greatly appreciated is the technical assistance of staff of the Department of Field Crops and Grassland Science, Agricultural University, Wageningen, with the chemical analyses, and of Mrs G. M. Meiburg, CSIRO, Division of Tropical Crops and Pastures with some of the anatomical measurements.

The senior author wishes to thank the CSIRO Division of Tropical Crops and Pastures for the travel costs of the visit of the Netherlands, and also the Agricultural University Wageningen for the award of a Visiting Professorship to enable this work to be undertaken.

\section{References}

Akin, D. E., 1982. Section to slide technique for study of forage anatomy and digestion. Crop Science 22: 444-446.

Akin, D. E., 1986. Chemical and biological structure in plants as related to microbial degradation of forage cell walls. In: L. P. Milligan, W. L. Grovum \& A. Dobson (Eds), Control of digestion and metabolism in ruminants, p. 139-157. Reston Books, New Jersey.

Akin, D. E., S. L. Fales, L. L. Rigsby \& M. E. Snook, 1987. Temperature effects on leaf anatomy, phenolic acids, and tissue digestibility in tall fescue. Agronomy Journal 79: 271-275.

Chesson, A., C. S. Stewart, K. Dalgarno \& T. P. King, 1986. Degradation of isolated grass mesophyll, epidermis and fibre cell walls in the rumen and by cellulolytic rumen bacteria in axenic culture. Journal of Applied Bacteriology 60: 327-336.

Cone, J. W. \& F. M. Engels, 1990. Influence of growth temperature on anatomy and in vitro digestion of maize tissues. Journal of Agricultural Science (Cambridge) 114: 207-212.

Da Silva, J. H. S., W. L. Johnson, J. C. Burns \& C. E. Anderson, 1987. Growth and environment effects on anatomy and quality of temperate and subtropical forage grasses. Crop Science 27: 1266-1273. 
Deinum, B., 1976. Effect of age, leaf number and temperature on cell wall and digestibility of maize. Wageningen Agricultural University Miscellaneous Papers No 12: 29-41.

Deinum, B., 1984. Chemical composition and nutritive value of herbage in relation to climate. In: H. Riley \& A. O. Skjelvag (Eds), Proceedings of the 10th General Meeting of the European Grassland Federation, p. 338-350.

Deinum, B. \& J. G. P. Dirven, 1976. Climate, nitrogen and grass. 7. Comparison of production and chemical composition of Brachiaria ruziziensis and Setaria sphacelata grown at different temperatures. Netherlands Journal of Agricultural Science 24: 67-78.

Deinum, B., J. de Beyer, P. H. Nordfeldt, A. Kornher, O. Ostgard \& G. van Bogaert, 1981. Quality of herbage at different latitudes. Netherlands Journal of Agricultural Science 29: 141-150.

Denne, M. P., 1971. Temperature and tracheid development in Pinus sylvestris seedlings. Journal of Experimental Botany 22: 362-370.

Dirven, J. G. P. \& B. Deinum, 1977. The effect of temperature on the digestibility of grasses. An analysis. Forage Research 3: 1-17.

Engels, F. M., 1989. Some properties of cell wall layers determining ruminant digestion. In: A. Chesson \& E. R. Orskov (Eds), Physico-chemical characterisation of plant residues for industrial and feed use, p. 80-87. Elsevier Applied Science, London/New York.

Fales, S. L., 1986. Effects of temperature on fiber concentration, composition, and in vitro digestion kinetics of tall fescue. Agronomy Journal 78: 963-966.

Ford, C. W., I. M. Morrison \& J. R. Wilson, 1979. Temperature effects on lignin, hemicellulose and cellulose in tropical and temperature grasses. Australian Journal of Agricultural Research 30: 621-633.

Goering, H. K. \& P. J. van Soest, 1970. Forage fiber analyses. United States Department of Agriculture Handbook No $379,20 \mathrm{pp}$.

Hattersley, P. W., 1987. Variations in photosynthetic pathway. In: T. R. Sodestrom, K. W. Hilu, C. S. Campbell \& M. E. Barkworth (Eds), Grass systemetics and evolution, p. 49-64. Smithsonian Institution Press, Washington.

Jenkins, P. A., 1975. Influence of temperature change on wood formation in Pinus radiata grown in controlled environments. New Zealand Journal of Botany 13: 579-592.

McDougall, E. I., 1948. The composition and output of sheep's saliva. Biochemical Journal 43: 99-109.

Moir, J. W., J. R. Wilson \& G. W. Blight, 1977. The in vitro digested cell wall and fermentation characteristics of grasses as affected by temperature and humidity during their growth. Journal of Agricultural Science (Cambridge) 88: 217-222.

Struik, P. C., B. Deinum \& J. M. P. Hoefsloot, 1985. Effects of temperature during different stages of development on growth and digestibility of forage maize (Zea mays. L.) Netherlands Journal of Agricultural Science 33: 405-420.

Wilson, J. R., 1982. Environmental and nutritional factors affecting herbage quality. In: J. B. Hacker (Ed.), Nutritional limits to animal production from pastures, p. 111-131. Commonwealth Agricultural Bureaux, Franham Royal, Slough, UK.

Wilson, J. R., D. E. Akin, M. N. McLeod \& D. J. Minson, 1989. Particle size reduction of the leaves of a tropical and temperate grass by cattle. II. Relation of anatomical structure to the process of leaf breakdown through chewing and digestion. Grass and Forage Science 44: 65-75.

Wilson, J. R. \& P. W. Hattersley, 1989. Anatomical characteristics and digestibility of leaves of Panicum and other grass genera with $\mathrm{C}_{3}$ and different types of $\mathrm{C}_{4}$ photosynthetic pathway. Australian Journal of Agricultural Research 40: 125-136.

Wilson, J. R. \& T. T. Ng, 1975. Influences of water stress on parameters associated with herbage quality of Panicum maximum var. trichoglume. Australian Journal of Agricultural Research 26: 127-136.

Wilson, J. R., A. O. Taylor \& G. R. Dolby, 1976. Temperature and atmospheric humidity effects on cell wall content and dry matter digestibility of some tropical and temperate grasses. New Zealand Journal of Agricultural Research 19: 41-46. 